8. Piot P, Plummer FA, Rey M-A, et al. Retrospective seroepidemiology of AIDS virus infection in Nairobi populations. J Infect Dis 1987; 155:110812.

9. Nsanze H, Fast MV, D'Costa LJ, Tukei P, Curran J, Ronald A. Genital ulcers in Kenya: clinical and laboratory study. Br J Vener Dis 1981; 57:37881 .

10. Plummer FA, D'Costa LJ, Nsanze H, Dylewski J, Karasira P, Ronald AR Epidemiology of chancroid and Haemophilus ducreyi in Nairobi. Lancet 1983; 2:1293-5.

11. D'Costa LJ, Plummer FA, Bowmer I, et al. Prostitutes are a major reservoir of sexually transmitted diseases in Nairobi, Kenya. Sex Transm Dis 1985 12:64-7.

12. Quinn TC, Glasser D, Cannon RO, et al. Human immunodeficiency virus infection among patients attending clinics for sexually transmitted diseases. N Engl J Med 1988; 318:197-203.
13. Hammond GW, Slutchuk M, Scatliff J, Sherman E, Wilt JC, Ronald AR Epidemiologic, clinical, laboratory, and therapeutic features of an urban outbreak of chancroid in North America. Rev Infect Dis 1980; 2:86779.

14. Blackmore CA, Limpakarnjanarat K, Rigau-Pérez JG, Albritton WL, Greenwood JR. An outbreak of chancroid in Orange County, California: descriptive epidemiology and disease-control measures. J Infect Dis 1985; 151:840-4.

15. Holmberg SD, Gerger AR, Stewart JA, et al. Herpesvirus as factors in infection with disease from human immunodeficiency virus (HIV): evidence that herpes simplex type 2 is a risk factor for HIV infection. Presented at the International Society for Sexually Transmitted Diseases Research, Atlanta, August 2-5, 1987. abstract.

16. Fink AJ. A possible explanation for heterosexual male infection with AIDS N Engl J Med 1986; 315:1167.

\title{
NEUROFIBROMATOSIS 2: CLINICAL AND DNA LINKAGE STUDIES OF A LARGE KINDRED
}

\author{
Wladimir Wertelegki, M.D., Guy A. Rouleau, M.D., Duane W. Superneau, M.D., \\ Lois W. Forehand, M.S., John P. Williams, M.D., \\ Jonathan L. Haines, Ph.D., and James F. Gusella, Ph.D.
}

\begin{abstract}
At least eight provisional categories of neurofibromatosis have been proposed. Among these, neurofibromatosis 1 (von Recklinghausen's disease or peripheral neurofibromatosis) and neurofibromatosis 2 (central or bilateral acoustic neurofibromatosis) have been established as distinct disorders.

We studied 15 affected male and 8 affected female members of one large kindred with neurofibromatosis 2. None of the patients met the diagnostic criteria for neurofibromatosis 1 . Between the ages of 15 and 53 years, the patients had multiple central nervous system tumors of various types - mainly, bilateral acoustic neuromas. Two or more tumors eventually developed in 20 of the patients; 9 had evidence of only bilater-
\end{abstract}

$\mathrm{A}^{\mathrm{F}}$ FER the studies of von Recklinghausen in 1882, the heterogeneous nature of neurofibromatosis was recognized. ${ }^{1,2}$ In 1903, Henneberg and Koch described "central" neurofibromatosis and emphasized the lack of skin alterations and the nosologic importance of acoustic neuromas. ${ }^{3}$ In 1915, Bassoe and Nuzum described a 15-year-old boy with multiple subcutaneous nodules, bilateral cerebellopontine angle tumors and multiple peripheral and central neurofibromas. ${ }^{4}$ In 1937, Worster-Drought et al. proposed a classification of neurofibromatosis based on the strict use of the terms "peripheral," "central," and "combined forms." ${ }^{5}$ Recently, Riccardi has proposed provisional categories of neurofibromatosis, designating them neurofibromatosis 1 through 7 and an eighth category of "not otherwise specified forms." 6 Consid-

From the Departments of Medical Genetics (W.W., D.W.S., L.W.F.) and Radiology (J.P.W.), University of South Alabama, the Neurogenetics Laboratory, Massachusetts General Hospital, and the Department of Genetics, Harvard Medical School, Boston (G.A.R., J.L.H., J.F.G.). Address reprint requests to Dr. Wertelecki at the Department of Medical Genetics, Rm. 214 CCCB, University of South Alabama, Mobile, AL 36688

Supported in part by grants from the National Institutes of Health, the Julieanne Dorn Fund for Neurological Research, the McKnight Foundation, the Neurofibromatosis Foundation, the Fond de Recherche en Sante du Quebec and a fellowship of the Medical Research Council of Canada (Dr. Rouleau) and a Searle Scholar Award of the Chicago Community Trust Funds (Dr. Gusella). al acoustic neuromas. Meningiomas and ependymomas were more common among the young patients; those who initially presented with acoustic neuromas were nearly a decade older. Intracranial nontumoral calcifications were present in most patients and were also found in symptom-free children. The presence of such lesions is probably a prodromic feature of neurofibromatosis 2 .

Simultaneous analysis of D22S1 and IGLV DNA markers for coinheritance with neurofibromatosis 2 indicates that the locus for the disease is near the center of the long arm of chromosome $22(22 q 11.1 \rightarrow 22 q 13.1)$. The eventual isolation of this disease gene may reveal a cause of the most common intracranial tumors in humans. (N Engl $\mathrm{J}$ Med 1988; 319:278-83.)

erable efforts to define the clinical and genetic heterogeneity of neurofibromatosis have culminated in a recent National Institutes of Health Consensus Development Conference Statement about "the neurofibromatoses." 7

Currently, there are two established forms of neurofibromatosis, and other variants are under study. The best known is the classic and common form, traditionally known as peripheral neurofibromatosis or von Recklinghausen's disease but now called neurofibromatosis 1 and recently related to a gene localized to chromosome 17 . The second form, which is now called neurofibromatosis 2, is rare and was historically known as central neurofibromatosis, or bilateral acoustic neuroma neurofibromatosis. ${ }^{7}$ The most recent diagnostic criteria proposed for neurofibromatosis 2 are bilateral acoustic neuromas or a first-degree relative with neurofibromatosis 2 and either a unilateral eighth-nerve mass, or two of the following: meningioma, glioma, schwannoma, neurofibroma, and juvenile posterior subcapsular lenticular opacity. ${ }^{7}$ The frequency of neurofibromatosis 2 is not known; its natural history was derived mainly from studies of one large family in Pennsylvania, begun by Gardner and colleagues more than half a century ago. ${ }^{8-12}$ 
Our studies focus on another large kindred manifesting neurofibromatosis $2 .^{13,14}$ Its size and accessibility made this family ideal for genetic-linkage investigations and determination of the natural history and clinical variability of the disease. Data from DNA-marker studies indicated that the gene causing neurofibromatosis 2 was in the immediate vicinity of the D22S1 locus. ${ }^{15}$ Now, after expanded linkage studies and multipoint linkage analysis, the data demonstrate that the gene causing neurofibromatosis 2 is near the center of the long arm of chromosome 22.

\section{Methods}

The white family studied is depicted in the pedigree in Figure 1 and resides mainly along the coast of the Gulf of Mexico. Medical records, histologic slides, death certificates, and autopsy reports were sought for all symptomatic family members. Clinical assessments were performed with use of a flow chart that included a search for signs of neurofibromatosis 1 . The results of computed tomography, magnetic resonance imaging, and ophthalmologic and audiologic examinations were also sought. Family members were considered to be affected only if evidence of tumors of the nervous system, its nerve sheaths, or enveloping membranes was demonstrated by surgery, biopsy, or imaging techniques. The studies were approved by our Committee for the Protection of the Rights of Human Subjects.

Peripheral-blood lymphocytes were obtained from 137 members of the kindred, and lymphoblastoid cell lines were established to provide a source of DNA. ${ }^{16}$ Two DNA markers, D22S $1,{ }^{17}$ an anonymous DNA locus, and IGLV, which encodes the variable-region segments of the immunoglobulin lambda light chain, were used to characterize family members. ${ }^{18}$ The D22S1 locus displays an apparent single-site restriction-fragment-length polymorphism with the use of the probe pMS3-18 and enzyme $B g l \mathrm{II}$. Allele 1, a fragment of $9.5 \mathrm{~kb}$, has a frequency of 0.81 , and allele 2 , a $6.5-\mathrm{kb}$ fragment, has a frequency of 0.19 . The probe pV3.3, containing a 3.3-kb Bam HI subclone

$$
\begin{aligned}
& \text { Male }=\square \quad O=\text { Female } \\
& ,=\text { Deceased } \\
& \delta=\text { Examined } \\
& \text { = Reported symptoms, unconfirmed } \\
& \odot=\text { obligate carrier } \\
& \checkmark=\text { Acoustic neuroma(s) } \\
& \square \mathcal{D}=\text { Meningioma(s) } \\
& O=\text { other CNS tumor(s) } \\
& \triangle \bigotimes=\text { Calcifications of the choroid plexus only }
\end{aligned}
$$

Figure 1. Family Pedigree of Patients with Neurofibromatosis 2.
VII
VI V IV III
II I
II III IV V VI VII

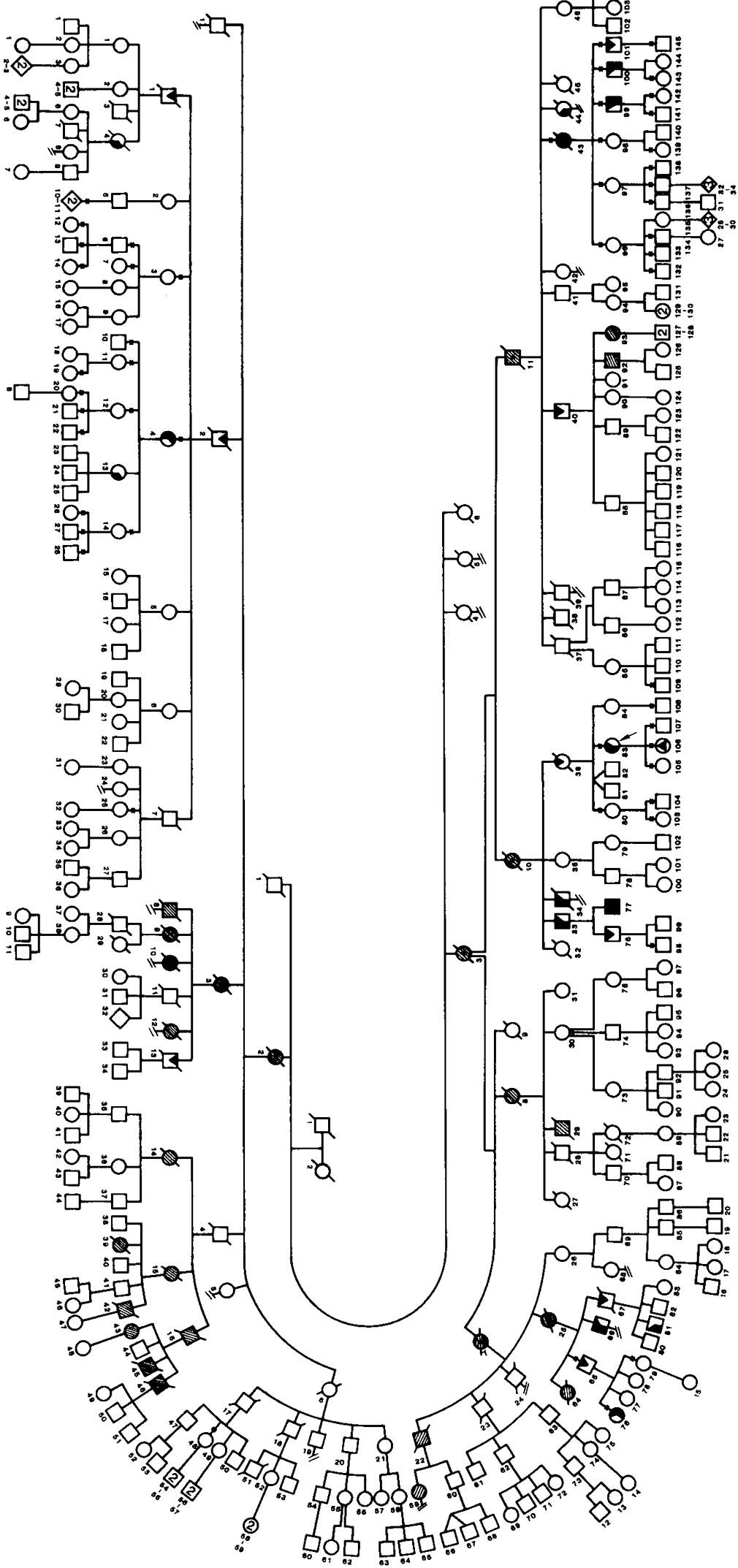

The New England Journal of Medicine 
fragment of the genomic clone V4A from the IGLV locus, detects a three-allele polymorphic system with the enzyme TaqI; the three allelic fragments, denoted here as A $(4.2 \mathrm{~kb}), \mathrm{B}(12.9 \mathrm{~kb})$, and $\mathrm{C}$ $(11.0 \mathrm{~kb})$, have frequencies of $0.13,0.55$, and 0.32 , respectively. ${ }^{19}$ Studies of normal families revealed a recombination frequency of 10 percent between these two markers. ${ }^{20}$

The data were analyzed with the computer programs LINK$\mathrm{AGE}^{21}$ and LIPED. ${ }^{22}$ The penetrance and mean age at onset were assumed to be 0.95 and 20 years, respectively. Further details about our methods are given elsewhere. ${ }^{15}$

\section{RESULTS}

The clinical manifestations in 15 affected male and 8 affected female family members were narrow in scope and directly related to emerging tumors. A typical medical history is that of a woman born in 1950 after an uneventful pregnancy, labor, and delivery (Fig. 1, Case V-83). At the age of 18 years, the patient noted increasing facial weakness on the right side and twitching of the lip and eyelid; three years later, she was unable to close her right eyelid. Progressive numbness and tingling in her legs led to a neurologic examination at the age of 26 years and the diagnosis of a 4-cm extra medullary spinal mass at the level of T7-T9 which, upon resection, was found to be a meningioma containing multiple calcified psammoma bodies. The facial paralysis progressed, and by the age of 30 years, there was loss of taste because of a right facial-nerve neuroma. One year later, dizziness, decreased brain-stem auditory evoked responses, and the results of computed tomography and encephalography led to the diagnosis of bilateral acoustic neuromas. Extensive choroid plexus calcifications were also observed. The tumor on the left side was resected, after which the patient became nonambulatory because of poor balance.

Soon after the resection, the patient had the onset of generalized pain that extended from the neck to the right shoulder and arm and was due to an extramedullary tumor at the level of C2-C3. Surgical exploration revealed a schwannoma at C2-C3 that was adjacent, but not attached, to a large extradural and intradural meningioma at C3-C4. In addition, an intradural meningioma en plaque was noted on the dorsal inner surface of the dura in the area of C1-C3. The tumor was partly removed, revealing multiple psammomatous bodies. A cystic lesion at the cervicomedullary junction revealed no neoplasia and contained cerebrospinal fluid.

At the age of 36 years, the patient was increasingly unable to hear, smell, taste, swallow, stand, or recall recent events. Examinations revealed three small café au lait spots but no axillary freckles, Lisch spots, or cutaneous neurofibromas. The patient reported that menarche (at age 12 years) and pregnancies (at age 21,24 , and 25 years) had not exacerbated her symptoms.

The patient has many similarly affected relatives (Fig. 1 and 2). An autosomal dominant pattern of inheritance was evident from the pedigree, with no instances of skipped generations between affected family members. Each patient met the National Insti- tutes of Health diagnostic criteria for neurofibromatosis 2, whereas none met the diagnostic criteria for neurofibromatosis $1 .^{7}$

The radiologic and histologic landmarks of these familial tumors revealed the usual features seen in similar tumors with a sporadic nature. On the other hand, intracranial nontumoral calcifications of unusual degree, extent, and location were found in 9 of 11 symptomatic and in 4 asymptomatic family members, 3 of whom subsequently had tumors. The fourth (VI106) was a six-year-old child who remains asymptomatic seven years later. A congenital cataract was found in one patient (V-101); statements about cataracts in two others (IV-43 and $\mathrm{V}-77$ ) could not be confirmed. Therefore, our data on the nosologic importance of cataracts in neurofibromatosis 2 are inconclusive. ${ }^{23}$ We found no indication that puberty, pregnancy, or maternal inheritance influenced the clinical course of the disease. ${ }^{24,25}$

Family members were typed for D22Sl and IGLV, and the results are shown in Table 1 as lod scores representing the $\log _{10}$ of the ratio of the likelihood of linkage to neurofibromatosis 2 and various recombination fractions $(\theta)$ relative to the likelihood of nonlinkage $(\theta=0.50)$. Generally, a lod score above +3 is considered proof of linkage, whereas a score below -2 excludes linkage at the specified $\theta$ value. Both markers yielded positive lod scores. The recombination value $(\hat{\theta})$ at which the maximum lod score $(\hat{\mathbf{z}})$ is obtained provides the best estimate of the recombination frequency separating the defect from the marker locus. For D22S1, the positive lod score had a maximum $\hat{\mathbf{z}}=3.42$ at $\hat{\theta}=0.00$, indicating that there were no obligate recombination events between the marker locus and the defective gene. IGLV yielded a positive lod score, with a maximum $\hat{\mathbf{z}}=0.95$ at $\hat{\boldsymbol{\theta}}=0.16$.

Knowledge of the frequency of recombination between these DNA markers permitted us to maximize the linkage information from our pedigree through simultaneous analysis of both marker loci for coinheritance with the disease gene. ${ }^{21}$ The multipoint analysis raised the peak lod score in favor of linkage to 4.05 (Fig. 3). Although the lod score was positive over a large region, the odds were approximately 10:1 against the disease locus being located on the centromeric side of the IGLV locus. The IGLV locus has been mapped to the $22 q 11.1 \rightarrow 22 q 11.2$ region. ${ }^{20,26}$ D22S1 maps less precisely to the $22 q 11.2 \rightarrow 22 q 13$ region, ${ }^{27}$ proximal to the marker SIS, which maps to $22 q 12.3 \rightarrow 22 q 13.1 .^{20,28}$ We conclude that the locus for neurofibromatosis 2 is located on the long arm of chromosome 22 , within a region 8 centimorgans proximal and 24 centimorgans distal to D22S1 (corresponding to the 1-lod unit confidence interval on the estimate of $\theta$ ).

\section{Discussion}

Our study of a large kindred manifesting neurofibromatosis 2 reaffirms the distinct and relatively narrow clinical scope of the disease. The four main noso- 
logic landmarks in this family are the postpubertal emergence of ependymomas, meningiomas, acoustic neuromas, and other tumors; the development of multiple tumors in virtually all patients; the lack of characteristics of neurofibromatosis 1 ; and an autosomal dominant inheritance pattern of high penetrance. As shown in Figure 2, nearly half the patients remained asymptomatic during their first 30 years of life, the youngest became symptomatic at the age of 15 years (V-13), and the oldest at the age of 53 years (IV-33). One patient (VI-76) remains asymptomatic at the age of 32. Initial symptoms attributable to acoustic neuroma appeared nearly a decade later than those attributable to meningiomas and ependymomas. Since tu-

\section{PEDIGREE}

NUMBER

AGE IN YEARS

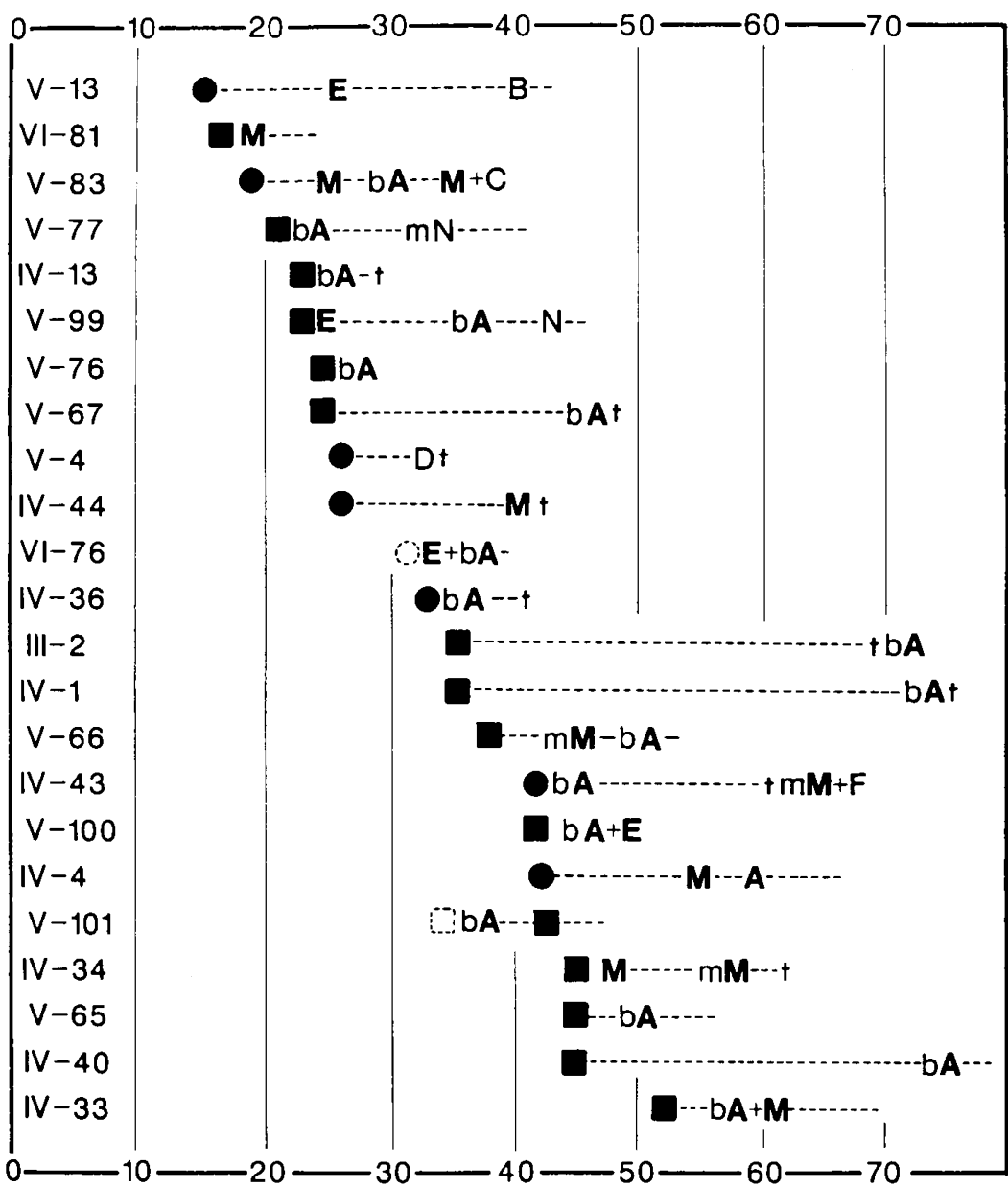

Report of Symptoms:

$D=$ Male $\quad=$ Female
$t=$ death
$b=$ bilateral
$m=$ multiple

Table 1. Lod Scores for Linkage of Neurofibromatosis 2 to D22S1 and IGLV.

\begin{tabular}{|c|c|c|c|c|c|c|c|c|}
\hline \multirow[t]{2}{*}{$\begin{array}{l}\text { MARKER } \\
\text { LOCUS }\end{array}$} & \multicolumn{7}{|c|}{ Recombinant Fraction $(\theta)$} & \multirow[t]{2}{*}{ PEAK LOD SCORE $(\boldsymbol{z}$} \\
\hline & 0.00 & 0.01 & 0.05 & 0.10 & 0.20 & 0.30 & 0.40 & \\
\hline $\mathrm{D} 22 \mathrm{~S} 1$ & 3.42 & 3.37 & 3.13 & 2.48 & 2.11 & 1.35 & 0.59 & $3.42(\hat{\theta}=0.00)$ \\
\hline IGLV & -0.20 & 0.04 & 0.60 & 0.86 & 0.93 & 0.72 & 0.37 & $0.95(\hat{\theta}=0.16)$ \\
\hline
\end{tabular}

mors that cause no symptoms are often found among relatives at risk, obtaining the family history is of exceeding importance in the diagnostic process. On the other hand, the presence of multiple nervous system tumors or bilateral acoustic neuromas, regardless of the family history, should arouse the suspicion that neurofibromatosis 2 is present, because such lesions are rare in the general population. Multiple meningiomas or spinal neurofibromas are uncommon, ${ }^{29,30}$ and less than 10 percent of acoustic neuromas are bilateral. ${ }^{31-33}$

The nontumoral calcifications found in a large proportion of patients were striking. These occurred in unusual areas of the choroid plexus, away from the glomus, or they revealed unusual configuration on the falx. These calcifications were similar to those observed in neurofibromatosis $1 .^{34-37}$ We suspect that further studies of this family will justify the view that nontumoral calcifications, mainly of the highly vascular choroid plexus, are prodromal features of neurofibromatosis 2. Tumoral calcifications are also seen in neurofibromatosis 1 and 2, and the tumors in these disorders are often highly vascular. Other vascular pathologic features have also been observed and have received increasing attention, but a relation of tumoral and nontumoral calcifications to such features in neurofibromatosis remains speculative. ${ }^{38-48}$

The isolation of the gene responsible for acoustic neuromas, meningiomas, ependymomas, and other tumors in neurofibromatosis 2 may elucidate a cause and influence treatment of the most common intracranial tumors in humans. ${ }^{49-61}$

Figure 2. Age at Onset of Symptoms and Diagnosis of Various Neoplasms. 


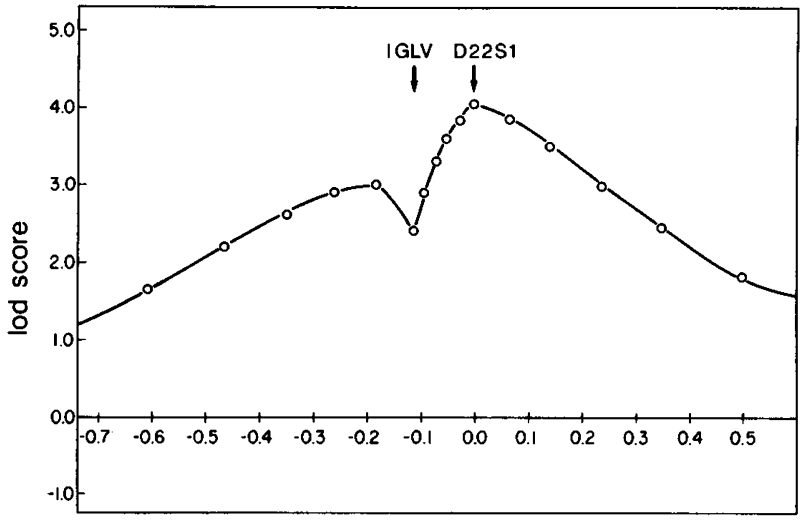

location

Figure 3. Lod Scores in Favor of Linkage Derived from Multipoint Analysis.

The locus of neurofibromatosis 1 is on chromosome $17^{62,63}$; in regard to neurofibromatosis 2 , there were several reasons to narrow the search to chromosome 22. Meningiomas and acoustic neuromas have a tendency to reveal a loss of chromosome $22 .{ }^{64,65}$ This common feature has suggested a similar pathogenesis for the lesions, although the loss of chromosome 22 may have been the result of secondary chromosomal events in tumorigenesis.

The family studies reported here have demonstrated an etiologic relation between a mutation of a gene on chromosome 22 and neurofibromatosis $2 .{ }^{15}$ The segregation data from two DNA markers and neurofibromatosis 2 in the family provide evidence that this mutation has a locus near the center of the long arm of chromosome 22. Although in some instances we can determine which individual family members carry the D22S1 allele, which is linked to the gene for neurofibromatosis 2, the available data are too limited to predict the frequency with which recombinations will occur between the locus for D22S1 and that for neurofibromatosis 2. Because our data were derived from one family, the genetic heterogeneity of neurofibromatosis 2 remains to be determined. However, we found that the clinical manifestations in our family were nearly identical to those in another large kindred manifesting neurofibromatosis $2 .^{8-12}$ In contrast, others have reported familial and sporadic occurrences of multiple central nervous system tumors in association with peripheral-nerve sheath tumors ${ }^{66-80}$ and even with pigmentary changes in skin. ${ }^{81-83}$ Thus, prospective DNA linkage studies will require considerable attention to the clinical categorization of such families.

Finally, predictive diagnostic tests also draw attention to psychosocial issues faced by symptomatic and particularly, by asymptomatic - affected family members. Many experience unforeseen anxieties, pressures, and demands from both within and outside their families. However, in neurofibromatosis 2, in contrast to Huntington's chorea (for which treatment options remain limited), the negative effects of pre- dictive diagnostic testing are tempered by potential advantages that can accrue from diagnosis before the appearance of symptoms, as well as early treatment. ${ }^{84}$

We are indebted to Ms. Amelia Canfield, who promoted this project, and to Dr. Henry Urich and Dr. Leonard S. Rich for sharing with us their expertise in neuropathology and ophthalmology.

\section{REFERENCES}

1. von Recklinghausen $\mathbf{F}$. Ueber die multiplen Fibrome der Haut und ihre Beziehung zu den multiplen Neuromen. Berlin: Hirschwald, 1882.

2. Crump T. Translation of case reports in Ueber die multiplen Fibrome der Haut und ihre Beziehung zu den multiplen Neuromen by F.v. Recklinghausen. Adv Neurol 1981; 29:259-75.

3. Henneberg, Koch M. Ueber "centrale" Neurofibromatose und die Geschwülste des Kleinhimbrückenwinkels (Acusticusneurome). Arch Psychiatrie 1902; 36:251-304.

4. Bassoe P, Nuzum F. Report of a case of central and peripheral neurofibromatosis. J Nerv Ment Dis 1915; 42:785-96.

5. Worster-Drought C, Carnegie Dickson WE, McMenemey WH. Multiple meningeal and perineural tumours with analogous changes in the glia and ependyma (neurofibroblastomatosis): with report of two cases. Brain 1937; 60:85-117.

6. Riccardi VM, Eichner JE, eds. Neurofibromatosis. Baltimore: Johns Hopkins University Press, 1986:169-83.

7. National Institutes of Health Consensus Development Conference Statement. Neurofibromatosis 1987; 6:1-7.

8. Gardner WJ, Frazier CH. Bilateral acoustic neurofibromas: a clinical study and field survey of a family of five generations with bilateral deafness in thirty-eight members. Arch Neurol Psychiatr 1930; 23:266-302.

9. Gardner WJ. Tumor of the spinal cord associated with bilateral acoustic tumors: report of a case. Arch Neurol Psychiatr 1930; 24:1014-22.

10. Gardner WJ, Turner $\mathbf{O}$. Bilateral acoustic neurofibromas: further clinical and pathologic data on hereditary deafness and Recklinghausen's disease. Arch Neurol Psychiatr 1940; 44:76-99.

11. Young DF, Eldridge R, Gardner WJ. Bilateral acoustic neuroma in a large kindred. JAMA 1970; 214:347-53.

12. Young DF, Eldridge R, Nager GT, Deland FH, McNew J. Hereditary bilateral acoustic neuroma (central neurofibromatosis). Birth Defects 1971; 7:73-86.

13. Superneau DW, Wertelecki W, Conneally PM. Central neurofibromatosis. Am J Hum Genet 1982; 34:111A. abstract.

14. Wertelecki W, Superneau DW, Forehand L. Neurofibromatosis II (acoustic neuroma-meningioma). Am J Med Genet 1988; 29:Suppl 4:184-5.

15. Rouleau GA, Wertelecki W, Haines JL, et al. Genetic linkage of bilateral acoustic neurofibromatosis to a DNA marker on chromosome 22. Nature 1987; 329:246-8.

16. Anderson MA, Gusella JF. Use of cyclosporin A in establishing EpsteinBarr virus-transformed human lymphoblastoid cell lines. In Vitro 1984; 20:856-8.

17. Barker D, Schafer M, White R. Restriction sites containing CpG show a higher frequency of polymorphism in human DNA. Cell 1984; 36:131-8.

18. Anderson MLM, Szajnert MF, Kaplan JC, McColl L, Young BD. The isolation of a human $\mathrm{Ig} \mathrm{V}_{\lambda}$ gene from a recombinant library of chromosome 22 and estimation of its copy number. Nucleic Acids Res 1984; 12 : 6647-61.

19. Julier C, Lathrop M, Lalouel JM, Reghis A, Szajnert MF, Kaplan JC. New restriction fragment length polymorphisms on human chromosome 22 at loci SIS, MB and IGLV. Cytogenet Cell Genet 1985; 40:664. abstract.

20. Julier C, Reghis A, Szajnert MF, Kaplan JC, Lathrop GM, Lalouel JM. A preliminary linkage map of human chromosome 22. Cytogenet Cell Genet 1985; 40:665. abstract.

21. Lathrop GM, Lalouel JM, Julier C, Ott J. Strategies for multilocus linkage analysis in humans. Proc Natl Acad Sci USA 1984; 81:3443-6.

22. Ott J. A computer program for linkage analysis of general human pedigrees. Am J Hum Genet 1976; 28:528-9.

23. Pearson-Webb MA, Kaiser-Kupfer MI, Eldridge R. Eye findings in bilateral acoustic (central) neurofibromatosis: association with presenile lens opacities and cataracts but absence of Lisch nodules. N Engl J Med 1986; 315:1553-4.

24. Miller M, Hall JG. Possible maternal effect on severity of neurofibromatosis. Lancet 1978; 2:1071-3.

25. Riccardi VM, Wald JS. Discounting an adverse maternal effect on severity of neurofibromatosis. Pediatrics 1987; 79:386-93.

26. Emanuel BS, Cannizzaro LA, Magrath I, Tsujimoto Y, Nowell PC, Croce CM. Chromosomal orientation of the lambda light chain locus: $V_{\lambda}$ is proximal to $C_{A}$ in 22q11. Nucleic Acids Res 1985; 13:381-7.

27. Naylor SL, Sakaguchi AY, Barker D, White R, Shows TB. DNA polymorphic loci mapped to human chromosomes $3,5,9,11,17,18$, and 22 . Proc Natl Acad Sci USA 1984; 81:2447-51. 
28. Jhanwar SC, Neel BG, Hayward WS, Chaganti RSK. Localization of the cellular oncogenes $A B L, S I S$, and $F E S$ on human germ-line chromosomes. Cytogenet Cell Genet 1984; 38:73-5

29. Nakasu S, Hirano A, Shimura T, Llena JF. Incidental meningiomas in autopsy study. Surg Neurol 1987; 27:319-22.

30. Levy WJ, Latchaw J, Hahn JF, Sawhny B, Bay J, Dohn DF. Spinal neurofibromas: a report of 66 cases and a comparison with meningiomas. Neurosurgery 1986; 18:331-4.

31. Cushing $\mathbf{H}$. Tumors of the nervus acusticus and the syndrome of the cerebellopontile angle. Philadelphia: W.B. Saunders, 1917:1-296.

32. Erickson LS, Sorenson GD, McGavran MH. A review of 140 acoustic neurinomas (neurilemmoma). Laryngoscope 1965; 75:601-27.

33. Tos M, Thomsen J. Epidemiology of acoustic neuromas. J Laryngol Otol 1984; 98:685-92.

34. Kendall B, Cavanagh N. Intracranial calcification in paediatric computed tomography. Neuroradiology $1986 ; 28: 324-30$.

35. Zatz LM. Atypical choroid plexus calcifications associated with neurofibromatosis. Radiology 1968; 91:1135-9.

36. Arts WFM, Van Dongen KJ. Intracranial calcified deposits in neurofibromatosis. J Neurol Neurosurg Psychiatry 1986; 49:1317-20.

37. Van Tassel P, Yeakley JW, Lee KF. Cerebellar calcification in central neurofibromatosis: CT in two cases. AJNR 1987; 8:913-5.

38. Halper J, Scheithauer BW, Okazaki H, Laws ER Jr. Meningio-angiomatosis: a report of six cases with special reference to the occurrence of neurofibrillary tangles. J Neuropathol Exp Neurol 1986; 45:426-46.

39. Kasantikul V, Netsky MG. Combined neurilemmoma and angioma: tumor of ectomesenchyme and a source of bleeding. J Neurosurg 1979; 50:81-7.

40. Bojsen-Møller M, Spaun E. Peripheral nerve tumour composed of neurilemmoma and haemangioma elements. Acta Neurochir (Wien) 1978; 40:299. 305.

41. Reubi F. Neurofibromatose et lésions vasculaires. Schweiz Med Wochenschr 1945; 26:463-5.

42. Wertelecki W, Superneau DW, Blackburn WR, Varakis JN. Neurofibromatosis, skin hemangiomas, and arterial disease. Birth Defects 1982; 18:29-41

43. Crome L. A case of central neurofibromatosis. J Pathol Bacteriol 1954; 67:407-17

44. Rubinstein $\mathrm{LJ}$. The malformative central nervous system lesions in the central and peripheral forms of neurofibromatosis: a neuropathological study of 22 cases. Ann NY Acad Sci 1986; 486:14-29.

45. Folkman $\mathbf{J}$. How is blood vessel growth regulated in normal and neoplastic tissue? Cancer Res 1986; 46:467-73.

46. Roche WR. Mast cells and tumour angiogenesis: the tumour-mediated release of an endothelial growth factor from mast cells. Int J Cancer 1985; 36:721-8.

47. Riccardi VM. Mast-cell stabilization to decrease neurofibroma growth: pre liminary experience with ketotifen. Arch Dermatol 1987; 123:1011-6.

48. Claman HN. New hope for neurofibromatosis? - The mast cell connection JAMA $1987 ; 258: 823$.

49. Dutcher PO Jr, House WF, Hitselberger WE. Early detection of small bilateral acoustic tumors. Am J Otol 1987; 8:35-8.

50. Martuza RL, Parker SW, Nadol JB Jr, Davis KR, Ojemann RG. Diagnosis of cerebellopontine angle tumors. Clin Neurosurg 1984; 32:177-213.

51. House WF. Partial tumor removal and recurrence in acoustic tumor surgery. Arch Otolaryngol 1968; 88:644-54.

52. House JW, Waluch V, Jackler RK. Magnetic resonance imaging in acoustic neuroma diagnosis. Ann Otol Rhinol Laryngol 1986; 95:16-20

53. Tator $\mathrm{CH}$. Acoustic neuromas: management of 204 cases. Can J Neurol Sci $1985 ; 12: 353-7$

54. Wiet RJ, Kazan RP, Raslan W, Herzon GD. Complications in the approach to acoustic tumor surgery. Ann Otol Rhinol Laryngol 1986; 95:28-31.

55. Cohen NL, Hammerschlag P, Berg H, Ransohoff J. Acoustic neuroma surgery: an eclectic approach with emphasis on preservation of hearing. Ann Otol Rhinol Laryngol 1986; 95:21-7.

56. Mattox DE. Vestibular schwannomas. Otolaryngol Clin North Am 1987; 20:149-60.

57. Glasscock ME III, Kveton JF, Jackson CG, Levine SC, McKennan KX. A systematic approach to the surgical management of acoustic neuroma. Laryngoscope $1986 ; 96: 1088-94$.
58. Cohn AI, Le Liever WC, Hokanson JA, Quinn FB Jr. Acoustic neurinoma diagnostic model evaluation using decision support systems. Arch Otolaryngol Head Neck Surg 1986; 112:830-5.

59. Perneczky A. Blood supply of acoustic neurinomas. Acta Neurochir (Wien) 1980; 52:209-18.

60. Nehls DG, Spetzler RF, Shetter AG, Sonntag VKH. Application of new technology in the treatment of cerebellopontine angle tumors. Clin Neurosurg $1984 ; 32: 223-41$.

61. Norén G, Amdt J, Hindmarsh T. Stereotactic radiosurgery in cases of acoustic neurinomas: further experiences. Neurosurgery 1983; 13:12-22.

62. Barker D, Wright $T$, Nguyen $\mathbf{K}$, et al. Gene for von Recklinghausen neurofibromatosis is in the pericentromeric region of chromosome 17 . Science 1987; 236:1100-2.

63. Seizinger BR, Rouleau GA, Ozelius LJ, et al. Genetic linkage of von Recklinghausen neurofibromatosis to the nerve growth factor receptor gene. Cell 1987; 49:589-94.

64. Zang KD. Cytological and cytogenetical studies on human meningioma. Cancer Genet Cytogenet 1982; 6:249-74.

65. Seizinger BR, Martuza RL, Gusella JF. Loss of genes on chromosome 22 in tumorigenesis of human acoustic neuroma. Nature 1986; 322:644-7.

66. Moyes PD. Familial bilateral acoustic neuroma affecting 14 members from four generations: case report. J Neurosurg 1968; 29:78-82.

67. Hitselberger WE, Hughes RL. Bilateral acoustic tumors and neurofibromatosis. Arch Otolaryngol 1968; 88:700-11.

68. Jones RM, Stewart IF, House WF. Familial central neurofibromatosis. Otolaryngol Head Neck Surg 1983; 91:527-31.

69. Feiling A, Ward E. A familial form of acoustic tumour. Br Med J 1920; 1:496-7.

70. Penfield W, Young AW. The nature of von Recklinghausen's disease and the tumors associated with it. Arch Neurol Psychiatr 1930; 23:32044.

71. Minski L. Familial bilateral acoustic tumours. J Neurol Psychopathol 1932; 12:289-308.

72. Roger H, Alliez J, Sarradon P. Tumeur bilatérale de l'acoustique à forme familiale et héréditaire. Bull Mem Soc Med Hop Paris 1934; 50:23540

73. Tumer OA, Gardner WJ. Familial involvement of the nervous system by multiple tumors of the sheaths and enveloping membranes: hereditary, clinical, and pathological study of central and peripheral neurofibromatosis. Am J Cancer 1938; 32:339-60.

74. Nager GT. Association of bilateral VIIlth nerve tumors with meningiomas in von Recklinghausen's disease. Laryngoscope 1964; 74:122061.

75. Lee DK, Abbott ML. Familial central nervous system neoplasia: case report of a family with von Recklinghausen's neurofibromatosis. Arch Neurol 1969; 20:154-60

76. Alliez J, Masse J-L, Alliez B. Tumeurs bilatérales de l'acoustique et maladie de Recklinghausen observées dans plusieurs générations. Rev Neurol (Paris) 1975; 131:545-58.

77. Banerjee AK, Radhakrishnan K, Sawhney IMS, Gulati DR. Central neurofibromatosis. Clin Neurol Neurosurg 1982; 84:191-9.

78. Huson SM, Thrush DC. Central neurofibromatosis. Q J Med 1985; 55:21324.

79. Battersby RDE, Ironside JW, Maltby EL. Inherited multiple meningiomas: a clinical, pathological and cytogenetic study of an affected family. J Neurol Neurosurg Psychiatry 1986; 49:362-8

80. Fahlgren H, Müller R. Familjär förekomst av bilateral akustikustumör. Nord Med 1955; 53:237-9.

81. Revilla AG. Neurinomas of the cerebellopontile recess: a clinical study of one hundred and sixty cases including operative mortality and end results. Bull Johns Hopkins Hosp 1947; 80:254-96.

82. Delleman JW, De Jong JGY, Bleeker GM. Meningiomas in five members of a family over two generations, in one member simultaneously with acoustic neurinomas. Neurology 1978; 28:567-70.

83. Mashiyama S, Mori T, Seki H, Suzuki J. Multiple brain tumours with von Recklinghausen's disease. Acta Neurochir (Wien) 1987; 84:29-35.

84. Martuza RL, Eldridge R. Neurofibromatosis 2 (bilateral acoustic neurofibromatosis). N Engl J Med 1988; 318:684-8. 